\title{
Chronic Solvent Encephalopathy in a Printing Unit for Flexible Packaging
}

\author{
Aida Benzarti Mezni and Abdelmajid Ben Jemâa \\ Department of occupational medicine Rabta hospital University of Medicine of Tunis, \\ Tunisia
}

\section{Introduction}

The solvents are a large group of chemicals which are used industrially in the production of paints, glues, coatings, degreasing agents, dyes, polymers, pharmaceuticals and printing inks. They have three characteristics in common, namely they are volatile liquids at normal temperature, they are strongly lipophilic and most of them, if the dose is sufficiently high, affect the functioning of the central nervous system.

Exposure to organic solvents can occur by inhalation, ingestion or absorption through the skin, but inhalation is usually the main route of entry.

The health impact of workplace solvent exposure remains an issue of substantial interest and concern to occupational health professionals. In fact, there is a growing recognition that organic solvents are neurotoxic to the nervous system and its neuropsychological functions. For an agent to be neurotoxic, it must produce an adverse change in the structure and function of the nervous system following exposure to agents such as solvents.

It is generally accepted that workers exposed to solvents for a long time may develop a Chronic toxic encephalopathy (CTE). The clinical picture of CTE is dominated by vague and non specific symptoms such as irritability, headache, sleep disturbances, concentrations problems and impaired memory.

In 1985, a WHO Working Group presented diagnostic criteria and a classification for solvent-induced chronic toxic encephalopathy (CTE). In the same year, the "Workshop on neurobehavioral effects of solvents" in Raleigh, N.C., USA introduced a somewhat different classification for CTE. The objective of a systematic review of criteria for solvent-induced chronic toxic encephalopathy, was to study the diagnostic procedures that are used to establish the diagnosis of CTE, and the extent to which the diagnostic criteria and classification of the WHO, and the classification of the Raleigh Working Group, are applied. Thus a systematic search of studies on CTE was performed, and the diagnostic criteria and use of the WHO and Raleigh classifications were listed. They retrieved 30 original articles published in English from 1985 to 1998, in which CTE was diagnosed. Only two articles did not report the duration of solvent exposure. The type of solvent(s) involved was described in detail in four articles, poorly in 17 articles, and not at all in nine articles. Tests of general intelligence were used in 19 articles, and tests of both attention and mental flexibility and of learning and memory were used in 18 articles. Exclusion, by interview, of potentially confounding conditions, such as somatic diseases with central nervous effects and psychiatric diseases, was reported in 21 and 16 articles, respectively. In only six of the 
articles were both the WHO diagnostic criteria and the WHO or Raleigh classifications used. [1]

These organic solvents occupy an important place in most industrial sectors because of their interesting technological properties, particularly in the printing industry. In Europe, the use of solvents in printing inks represent $6 \%$ of their total industrial use.

In Tunisia, the sector of packaging and printing is an important industry. There are more than 350 companies employing about 17,000 workers.

The printing industry is one on of the sectors which expose workers to organic solvent. Some studies were performed on printing workers which are usually exposed to mixtures of organic solvents. In fact, Yu, Ignatius Tak-Sun MBBS and al showed in their study about occupational exposure to mixtures of organic solvents among printing workers in Hong Kong, that this exposure increases the risk of neurological Symptoms. It was a crosssectional survey conducted among 762 male printing workers to assess the impacts of exposure to mixtures of $n$-hexane, toluene, isopropyl alcohol, and benzene on neurological and other symptoms. After controlling for age, smoking, alcohol drinking, past exposure history, working hours and shift work, current exposure to solvent mixtures was significantly associated with the total number of neurological symptoms and with the prevalence of specific symptoms of the nervous system and mucous membrane irritation. The adjusted odds ratio of neurovegetative lability (1.7-5.9) and memory loss (1.8) were significantly increased in the exposed group, especially when the summation index of exposure exceeded one. Finally, the health effects of low-dose occupational exposure to organic solvents remained unclear. [2]

Another study addresses the prevalence of organic brain syndrome (OBS) among long-term toluene-exposed rotagravure workers who are still working. The prevalence of OBS in 22 workers exposed to toluene for a minimum of 12 years and 19 unexposed control subjects, matched for age and employment status, was assessed with a comprehensive clinical psychiatric interview. There was a significantly greater prevalence of mild chronic encephalopathy and organic affective syndrome in the toluene-exposed group. [3]

Elsewhere, a 2-year prospective study examined the neurobehavioral effects of acute and chronic exposure to mixed solvents in workers in a screen printing business. A total of 30 subjects participated in the study in two field testings over a 12 month period. Each subject completed a detailed medical and occupational questionnaire, had a neurological examination, and underwent a battery of neuropsychological tests. Industrial hygiene investigation identified the following chemical exposures as present: toluene, methyl ethyl ketone, mineral spirits, $\beta$-ether, methylene chloride, and acetic acid. Different departments and jobs had varying degrees of exposure to these chemicals, the highest exposures being in the ink mix area and the screen washroom area. However, all exposure levels were below recommended threshold limit values. Persons categorized as having higher acute exposure demonstrated significantly impaired test performance on tasks involving manual dexterity, visual memory, and mood. Those with higher chronic exposure demonstrated significantly poorer performance on visual memory tasks and mood. Results suggest that the mixed solvents used in the screen printing industry have an effect on central nervous system functioning in the absence of obvious clinical disease. [4]

Our study consists on a descriptive epidemiological survey with 75 employees working in a printing company for flexible packaging to detect chronic neuropsychological effects secondary to the manipulation of solvents by employees. 


\section{Objectives}

- Assess objectively the degree of exposure to solvents by an environmental study.

- $\quad$ Assess neuro-psychological effects related to chronic exposure to solvents

\section{Material and methods}

\subsection{Material}

1. Presentation of the company: The industrial company of packaging and derivatives is a print on flexible packaging for various food products, located in an industrial area. It has a large workshop with an area of $2000 \mathrm{~m} 2$ and about $8 \mathrm{~m}$ high divided into several units including:

- Print Soloflex

- $\quad$ Print Heliography

- Laminating

- $\quad$ Shop for storing raw materials and finished products

- $\quad$ Appendices located outside the main workshop used for the preparation of a mixture of inks and accessories for cleaning printing machines.

2. Population: The total number of employees in this company is 75 people divided into four occupational categories: managers, technicians, skilled and versatile workers. Employees are divided into two groups: one group exposed to solvents and other nonexposed group.

\subsection{Methodology}

Our study consisted of two parts:

- Environmental Study

- $\quad$ Medical study

\subsubsection{Environmental study}

- The qualitative assessment: It is based on an inventory of chemicals handled. Data collection was based on canvas: Outline for the handled products and canvas for post study.

It helped to develop a job-exposure matrix taking into account the following parameters: The exposure, the frequency of exposure and The length of the post

This matrix has identified three risk levels (high, moderate and low).

- The Quantitative assessment:

- Sampling techniques and analysis used:

The technical team carried out by sampling dynamic industrial pumps in the respiratory tract. The used adsorbent is activated carbon, the pumps are calibrated at a flow rate of $0.2 \mathrm{~L} / \mathrm{min}$. The average duration of each sample was $150 \mathrm{~min}$. A total of 8 samples were taken at different units studied covering two days of work. The samples were analyzed by gas chromatography after desorption with carbon disulfide (CS2). Analytes in air samples are determined by consulting the data sheets and safety are the following: ethyl acetate (TWA: $100 \mathrm{ppm}$ ), ethanol (TWA: 1000ppm), the methoxy propanol (TWA: 1000ppm). The values measured concentrations are compared to average values of exposure (international standards)

- Calculation of concentration index of the mixture: 
In the case of exposure to several substances whose effects are the same, we must take into consideration, to assess the average exposure (TWA), the sum of the effects of each substance. For this, we must determine the concentration index of the mixture which is calculated as follows: we determine the actual atmospheric concentration of each substance divided by its average value of exposure.

To meet the standard permissible concentration index of the mixture should not exceed unity.

$$
\mathrm{Rm}=\mathrm{C} 1 / \mathrm{N} 1+\mathrm{C} 2 / \mathrm{N} 2+\ldots . .+\mathrm{Cn} / \mathrm{Nn}
$$

$\mathrm{Rm}=$ concentration index of the mixture

... C1 ... Cn: actual concentration of substances N1 ... Nn ...: Standards Substance

\subsubsection{Medical study}

This is a transversal epidemiological study based on a set questionnaire, modelled on the Q16 usually used for the detection of neurotoxic effects in workers exposed to solvents. The questionnaire was administered by a physician to all employees. It included the following parts:

- Socio-professional employee

- $\quad$ The disease history and lifestyle.

- Health care consumption

- The functional neuro-psychological symptoms reported by patients

Solvent exposure was assessed by the research of direct handling of solvents or exposure to vapours from one or more positions of neighbourhoods, and our population was divided into two groups:

- The exposed group: those who directly handle solvents and those who do not handle solvents but are exposed to fumes from one or more positions of neighbourhoods (indirect exposure)

- The non exposed group: those who do not handle solvents and are not exposed to vapours from neighbourhoods posts (administrator, drivers).

The medical study included a descriptive and analytical part type exposed - unexposed.

The Statistical Analysis: Data entry and data analysis were performed by Epi Info version 6 . It is essentially a comparison of actual and number of responses between the group of exposed and unexposed. For this, we used the chi 2 test with a confidence interval of $95 \%$ which corresponds to a set $\mathrm{P}(0.05)$.

\section{Results}

\subsection{Qualitative assessment}

- Inventory of used products: Solvent exposure comes primarily from printing units, laminating, preparing ink, solvent recycling and cleaning accessories for printing machines. At these units the mostly used products were: ethyl acetate, ethanol and methoxy propanol.

- $\quad$ Post Study: There are several units within the company. (Table $\left.N^{\circ} 1\right)$

- Flexographic Printing

- Print Heliography

- laminating

- Appendices located outside the main workshop: 
- $\quad$ Preparation of ink mixing

- Cleaning accessories printing machines

- Solvent recycling

\begin{tabular}{|c|c|c|c|c|c|}
\hline Product & $\begin{array}{l}\text { Exposed } \\
\text { workers }\end{array}$ & Post & Quantity & Route exposure & $\begin{array}{c}\text { Conditions of } \\
\text { work }\end{array}$ \\
\hline \begin{tabular}{|l} 
- \\
- \\
- 1 pthanol \\
- 1 metopanol \\
propanol \\
- Isopropanol \\
- Propanol \\
- Ethoxyprop- \\
anol
\end{tabular} & 20 & \begin{tabular}{|l|} 
- Mixed ink \\
- Flexographic \\
and rotogravure \\
- complexing \\
paraffin \\
- Flexography \\
- heliograph
\end{tabular} & $70256 \mathrm{Kg} /$ mois & $\begin{array}{l}\text { - Cutaneous } \\
\text { - Respiratory }\end{array}$ & $\begin{array}{l}\text { - not wearing } \\
\text { PPE } \\
\text { - natural and } \\
\text { artificial } \\
\text { ventilation } \\
\text { provided by } \\
\text { windows, doors } \\
\text { and } 2 \text { extractors }\end{array}$ \\
\hline 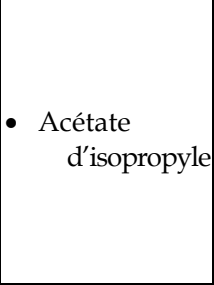 & 6 & $\begin{array}{l}\text { - Flexography } \\
\text { - Héliography } \\
\text { - complexing } \\
\text { paraffin } \\
\text { - Mixed ink }\end{array}$ & $\begin{array}{c}100,148 \mathrm{Kg} / \\
\text { mois }\end{array}$ & $\begin{array}{l}\text { - Cutaneous } \\
\text { - Respiratory }\end{array}$ & $\begin{array}{l}\text { - not wearing } \\
\text { PPE } \\
\text { - natural and } \\
\text { artificial } \\
\text { ventilation } \\
\text { provided by } \\
\text { windows, doors } \\
\text { and } 2 \text { extractors }\end{array}$ \\
\hline $\begin{array}{l}\text { - Acétate } \\
\text { d'éthyle }\end{array}$ & 28 & - all posts & $\begin{array}{c}106,148 \mathrm{Kg} / \\
\text { mois }\end{array}$ & $\begin{array}{l}\text {-Cutaneous } \\
\text { - Respiratory }\end{array}$ & $\begin{array}{l}\text {-not wearing } \\
\text { PPE unless the } \\
\text { worker in the } \\
\text { cleaning room } \\
\text { accessories, } \\
\text { wearing } \\
\text { unsuitable } \\
\text { masks } \\
\text { - natural and } \\
\text { artificial } \\
\text { ventilation } \\
\text { provided by } \\
\text { windows, doors } \\
\text { and } 2 \text { extractors } \\
\text { above the unit } \\
\text { flexography and } \\
\text { laminating }\end{array}$ \\
\hline
\end{tabular}

Table 1 . Fact handled by product

\subsection{Quantitative assessment}

We note that the average concentrations measured are below the requirement for the solvents tested in all units studied, but they do not reflect the reality of occupational exposure as employees of the units are exposed to a mixture of solvents, whose effects are identical, so we calculated the concentration index of the mixture. The results showed that the latter is less than 1 in all units studied. (Table $\mathrm{N}^{\circ} 2$, Table $\mathrm{N}^{\circ} 3$ ) 


\begin{tabular}{|c|c|c|c|c|}
\hline \multirow[b]{2}{*}{ Post } & \multirow{2}{*}{$\begin{array}{l}\text { Number of } \\
\text { sampls }\end{array}$} & \multicolumn{3}{|c|}{$\begin{array}{l}\text { Average concentrations of solventsanalyzed in air } \\
\qquad(\mathrm{ppm})\end{array}$} \\
\hline & & $\begin{array}{l}\text { Acétate d'éthyle } \\
\text { (VME }=400 \mathrm{ppm})\end{array}$ & $\begin{array}{c}\text { Ethanol } \\
\text { (VME }=1000 \text { ppm) }\end{array}$ & $\begin{array}{l}\text { Methoxypropyl } \\
\text { (VME=100 ppm) }\end{array}$ \\
\hline Heliography Unit & 2 & 102,3 & 36,6 & - \\
\hline $\begin{array}{l}\text { flexogarphy Unit } \\
\text { (Soloflex) }\end{array}$ & 1 & 73,7 & 83,5 & 5,7 \\
\hline $\begin{array}{l}\text { unit Lamination } \\
\text { simplex } \\
\text { unit of ink }\end{array}$ & 1 & 52,9 & - & 6,7 \\
\hline $\begin{array}{l}\text { Preparation for } \\
\text { Heliography } \\
\text { unit of ink }\end{array}$ & 1 & 158,6 & - & - \\
\hline $\begin{array}{l}\text { Preparation } \\
\text { Soloflex }\end{array}$ & 1 & 133,8 & 12,6 & - \\
\hline $\begin{array}{l}\text { unit of accessories } \\
\text { Cleaning }\end{array}$ & 2 & 359,9 & - & - \\
\hline
\end{tabular}

Table 2. Results of analysis of air samples by the workstation

\section{Post}

Héliography unit

Flexography unit

Soloflex

Unit of lamination simplex

Préparation unit of ink

Héliogarphy

Préparation unit

of ink

Soloflex

Unit of accessories Cleaning
Index of mixture

0,28

0,32

0,2

0,39

0,34

0,9

Table 3. Concentration index of the mixture per workstation

\subsection{Medical study}

\subsubsection{Descriptive study}

\subsubsection{Socio-occupational study of population:}

- $\quad$ Age: The average age is 40.6 years. More than half of the employees belong to the age group between 30 and 39 years.

- Sex: Sex - ratio M / F = 5.48. More than three quarters of the study population are men.

- Grade: Almost half the study population is not educated beyond the secondary level.

- Marital Status: Almost two thirds of the study population are married

- Professional Category: Two-thirds of the staff of this company is mainly represented by skilled and versatile workers. 
- $\quad$ Seniority in the workplace: The average tenure is 13.62 years \pm 9.63 .

- Exposure to solvents: it is noted that the study population is composed of 56 persons exposed and 18 unexposed people.

\subsubsection{Socio-occupational characteristics of exposed population}

- $\quad$ Average age is 40.59 years \pm 8.71 .

- Sex: Sex - ratio M / F = 6

- Qualification: Most of the papers or $87.5 \%$ are skilled and versatile workers.

- Seniority in the post: The average tenure is $13.7 \pm 9.5$. Most presentations have a length exceeding 16 years

- Exposure to solvents: There are two modes of exposure:

- An indirect exposure: it is the exposure to solvent vapours from one or more neighbourhood positions

- Direct exposure: that is to say direct handling of solvents (Table No. 4)

Direct exposure relates generally employees occupying the positions of printing, laminating, preparation of inks, accessories and cleaning solvent recycling.

The distribution of exposure by frequency of exposure revealed that exposure to solvents is essentially daily in $75 \%$ of cases. Employees who are exposed for a few days a month and a few days a week does not exceed $1 / 4$ of the actual presentation is $25 \%$ (Table No. 5)

\begin{tabular}{ccc}
\hline Exposition & Number & $\%$ \\
Direct exposure & 38 & 67,9 \\
Non direct exposure & 18 & 32,1 \\
Total & 56 & $100 \%$ \\
\hline
\end{tabular}

Table 4. Distribution of risk by mode of exposure

\begin{tabular}{lcc}
\hline \multicolumn{1}{c}{ Exposure frequency } & Number & $\%$ \\
Daily & 42 & 75,0 \\
A few times a week & 9 & 16,0 \\
A few times a month & 5 & 8,9 \\
Total & 56 & $100 \%$ \\
\hline
\end{tabular}

Table 5. Distribution of exposure by frequency of exposure

The qualitative assessment of exposure:

Matrix: Exposure Mode - Frequency: According to this matrix "exposure mode, exposure frequency" we can identify four groups of exposure. (Table No. 6)

\begin{tabular}{lcc}
\hline \multicolumn{1}{c}{ Exposure frequency } & \multicolumn{2}{c}{ Exposure mode } \\
Daily & Direct Exposure & Non direct Exposure \\
A few times a week & 33 & 9 \\
A few times a month & 3 & 6 \\
Total & 2 & 3 \\
\hline
\end{tabular}

Table 6. Distribution of exposure by mode and frequency of exposure

G1: very important Exposure: 33 persons (daily direct exposure) 
G2: High exposure: 12 people (direct exposure within a few times a week or daily indirect exposure) G3: Moderate exposure: 8 persons (direct exposure within a few times a month or indirect exposure within a few times a week)

G4: Low exposure: 3 persons (indirect exposure a few times a month)

The distribution of the four exposure groups G1, G2, G3 and G4 by seniority in the workplace, we deduce the following results: (Table $\mathrm{N}^{\circ} 7$ )

- $\quad$ Limited exposure to moderate with a seniority of less than 10 years: 6 workers

- Important or very important exposure with seniority less than 10 years: 18 workers.

- $\quad$ Limited exposure to moderate with seniority above 10 years: 5 workers.

- Important or very important exposure with seniority above 10 years: 27 workers.

These results can be summarized as three levels of risk taking into account both the three parameters discussed below:

- The mode of exposure (direct or indirect)

- The frequency of exposure

- $\quad$ The length of the post (Table $\left.N^{\circ} 8\right)$

\begin{tabular}{ccccc}
\hline Seniority & Low & Moderate & High & Very important \\
{$[0-5]$} & 1 & 1 & 2 & 1 \\
{$[6-10]$} & 0 & 4 & 3 & 12 \\
{$[11-15]$} & 2 & 2 & 1 & 12 \\
{$[16-35]$} & 0 & 1 & 6 & 8 \\
\hline
\end{tabular}

Table 7. Distribution of the four exposure groups based on post seniority

\begin{tabular}{ccc}
\hline Level of risk & Number & $\%$ \\
High & 27 & 48,2 \\
Moderate & 23 & 41,1 \\
Low & 6 & 10,7 \\
\hline
\end{tabular}

Table 8. Distribution of the population exposed based on the level of risk

\subsubsection{Clinical characteristics of the exposed population:}

- Disease history: Three quarters of the exposed population have no previous medical history.

- Consumer Care: Individuals exposed to solvents consume mainly analgesics (78.6\%)

- Tobacco use: The majority of people exposed to solvents in this business are not smokers. $(62.5 \%)$

- Alcohol: 7.1\% of workers consume occasionally alcohol.

- Various neuropsychiatric symptoms: They were noted in almost the exposed patients, at least one functional neuro event. The main found neuropsychiatric complaints neuropsychiatric disorders, sleep, memory problems, headaches and physical fatigue. Headaches occur mainly at the end of workday. Are sleep disorders are dominated by insomnia that manifests itself by early morning awakening. (Table $N^{\circ} 9$ ).

We note also that most people with a neuropsychological complaint $(89.3 \%)$ belongs to level 1 or 2 (Table $\left.N^{\circ} 10\right)$

Furthermore, we were able to identify two types of syndromes: the acquired syndrome of intolerance to vapours of solvent organic psychosyndrome and psychosyndrome that appears most frequently (Table $N^{\circ} 11$, Table $N^{\circ} 12$ ) 


\begin{tabular}{ccc}
\hline & Number & $\%$ \\
Memory impairment & 36 & 64,3 \\
Sleep disorders & 56 & 100 \\
Headache & 32 & 57,1 \\
Weakness and fatigue & 33 & 58,9 \\
Tightness in chest & 22 & 39,3 \\
Feeling faint & 30 & 53,6 \\
Tremor exaggerated hands & 22 & 39,3 \\
Tingling or tingling in hands or legs & 17 & 30,4 \\
Sexual dysfunction: frigidity in women and & 20 & 35,7 \\
decreased libido in men & 24 & 42,9 \\
\hline
\end{tabular}

Table 9. Neuropsychiatric manifestations in exposed workers

\begin{tabular}{ccc}
\hline Level of risk & Nombre & $\%$ \\
Level 1 & 27 & 48,2 \\
Level 2 & 23 & 41,1 \\
Level 3 & 6 & 10,7 \\
Total & 56 & $100 \%$ \\
\hline
\end{tabular}

Table 10. Distribution of presentations on functional neuro symptoms by level of risk

\begin{tabular}{|c|c|c|c|c|c|}
\hline $\mathrm{N}^{\circ}$ & age & Sex & Post & Seniority & Level of risk \\
\hline 1 & 26 & M & $\begin{array}{l}\text { Recyclage des } \\
\text { solvants }\end{array}$ & 5 & 2 \\
\hline 2 & 48 & M & Printing & 27 & 1 \\
\hline 3 & 49 & M & Préparation of ink & 18 & 1 \\
\hline 4 & 49 & M & $\begin{array}{l}\text { Cleaning of a } \\
\text { accessoires }\end{array}$ & 27 & 1 \\
\hline 5 & 47 & M & Printing & 23 & 1 \\
\hline 6 & 30 & M & $\begin{array}{c}\text { Cleaning of a } \\
\text { accessoires }\end{array}$ & 5 & 1 \\
\hline 7 & 37 & M & Printing & 5 & 1 \\
\hline 8 & 45 & M & Cutting & 27 & 1 \\
\hline
\end{tabular}

Table 11. Distribution of organic psychosyndrome by level of risk and according to socioprofessional caracteristics

The 8 people identified as having solvent organic psychosyndrome are male and have a minimum of 5 years of exposure. They hold positions considered most at risk. Half of these men have they consulted a doctor other than the physician work. Among the eight cases of organic psycho syndrome, four were able to benefit of an neuropsychological exploration performed by the same psychologist and it was based on battery of psychometric tests or tests of intellectual efficiency which attach to assess mental deterioration and to search the organicity by offering tests exploring: (Table $N^{\circ} 13$ )

- $\quad$ memory working (span, semantic, episodic verbal, immediate visual ...) 


$\begin{array}{cccc}\begin{array}{c}\text { Neuropsychological } \\ \text { complaints }\end{array} & \text { Exposed (56) } & \text { Non exposed (18) } & \mathbf{P} \\ \text { Memory Disorders } & 36 & 7 & \mathrm{~S}<<0,05 \\ \text { Headache } & 32 & 2 & \mathrm{~S}<<0,05 \\ \text { Sleep Disorders } & 56 & 8 & \mathrm{~S}<<0,05 \\ \text { Physical fatigue } & 33 & 2 & \mathrm{~S}<<0,05 \\ \text { Chest tightness } & 22 & 3 & \mathrm{~S}<<0,05 \\ \text { Sensation of weakness } & 30 & 4 & \mathrm{~S}<<0,05 \\ \text { throughout the body } & 22 & 1 & \mathrm{~S}<<0,05 \\ \quad \text { Fainting } & 20 & 3 & \mathrm{~S}<<0,05 \\ \text { Tingling tingling of the } & 17 & 2 & \mathrm{~S}<<0,05 \\ \text { hands or legs } & & 1 & \mathrm{~S}<<0,05 \\ \text { Tremor exaggerated } & 18 & 2 & \mathrm{~S}<<0,05 \\ \quad \text { hands } & 24 & & \end{array}$

Table 13. Distribution of exposed and unexposed workers according to the neuropsychological encountered complaints

\begin{tabular}{|c|c|c|c|c|}
\hline Cases & Post & Age & Seniority & $\begin{array}{c}\text { Neuropsychological } \\
\text { Exploration }\end{array}$ \\
\hline Case 1 & Cleaning agent pieces & $\begin{array}{c}30 \\
\text { years }\end{array}$ & 5 years & $\begin{array}{l}\text { - Deficit in working } \\
\text { memory, semantic, and } \\
\text { episodic verbal } \\
\text { - Deficit of executive } \\
\text { functions } \\
\text { - State anxiety depression }\end{array}$ \\
\hline Case 2 & $\begin{array}{l}\text { - Score printing } \\
\text { machine } \\
\text { - Cleaner Parts }\end{array}$ & $\begin{array}{c}49 \\
\text { years }\end{array}$ & 27 years & $\begin{array}{l}\text { - Deficit in working } \\
\text { memory, semantic, and } \\
\text { immediate verbal episodic } \\
\text { verbal memory, Visio } \\
\text { spatial } \\
\text { - Deficit of executive } \\
\text { functions }\end{array}$ \\
\hline Case 3 & Preparation of inks & $\begin{array}{c}49 \\
\text { years }\end{array}$ & 18 years & $\begin{array}{l}\text { - Alteration of executive } \\
\text { functions } \\
\text { - Depression }\end{array}$ \\
\hline Case 4 & $\begin{array}{l}\text { recycling solvents } \\
\text { platemaking Post }\end{array}$ & $\begin{array}{c}26 \\
\text { years }\end{array}$ & 5 years & $\begin{array}{l}\text { - Problems with verbal } \\
\text { episodic memory } \\
\text { - Trouble in working } \\
\text { memory } \\
\text { - behavior disorder } \\
\text { - impulsive behaviour }\end{array}$ \\
\hline
\end{tabular}

Table 14. Distribution of exposed workers with organic psychosyndrome according the neuropsychological tests 
- $\quad$ attention (selective, divided)

- executive functions (conceptual development, categorization, cognitive inhibition ability ..)

- constructive and Visio spatial functions (or Rey figure memory test of 15 words of Rey)

- personality

\subsubsection{Analytical study}

- Matching by age, sex and age: The difference regarding age, gender and seniority to the position between the two populations (exposed and unexposed) is not significant.

- Medical history: The two populations (exposed and unexposed) did not differ regarding disease history

- Lifestyle: The difference is not significant in terms of consumption of tobacco and alcohol between the exposed and unexposed

- Use of health care: there is no significant difference regarding the consumption of care.

- Functional neuropsychological symptoms: A significant difference was found between the two groups in the neuropsychiatric manifestations $(\mathrm{P}<<0.05)$ (Table $N^{\circ}$ 14)

\section{Discussion}

The solvents are a family of chemicals widely used in the formulation of many products used as industrial inks. In Europe, the use of solvents in printing inks represents $6 \%$ of their total industrial use. This expansion of the printing industry was accompanied by a remarkable use of these products could have adverse consequences on the health of workers in particular neuropsychiatric effects [5]

Indeed toxic encephalopathy due to solvents is described in more than half a century it has been reported in several studies concerned with some occupationally exposed groups. However, studies are not all consistent, the differences found between exposed and unexposed are minimal and abnormalities objectified by complementary neurophysiologic investigations are inconsistent.

At the individual level, the diagnosis is difficult because there are no specific additional review.

The neurotoxicity with exceeding doses of solvents is well known for a long time, but is there a neurological syndrome solvents at low dose? Several questions: what is the reality of the risk when exposed to low dose? How to evaluate and measure exposure? There is usually poly-exposure to many products, often mixed. These mixtures are they most often involved .....

The cutaneous or respiratory penetration influences such as the evolution toward dementia. Early detection is it possible? [6]

The choice of studying of the neurological effects of solvents emanates from the importance of this effect on the frequency, severity and speed of installation [7]

Thus, we were interested in this work in search of neuropsychological effects of solvent with 75 employees of a Tunisian company of package printing.

Solvent exposure was demonstrated at first by a qualitative with a job exposure matrix taking into account three parameters: the mode, frequency and duration of exposure. This assessment was completed in a second time by a quantitative assessment. 
Qualitative assessment:

The inventory of used products was based on analysis of safety data sheets which revealed several types of solvents handled by the employee as follows: alcohol (methoxy-propanol ...) ethyl acetate .... ..

The study of work stations and interrogation of employees has allowed us to classify the workers: directly exposed, indirectly exposed and not exposed to solvents. Concentrations recorded by atmospheric monitoring for the following solvents: ethyl acetate, ethanol and iso-propanol was lower than the TWA and the same for the concentration of the mixture index, despite the absence of individual and collective preventive measures. This reduces the interest of regularly controlling atmospheric monitoring for the exposed workers. [7]

Socio-professional characteristics:

Our study population consists of 75 employees working for at least a year. It is a predominantly male population (sex ratio $\mathrm{M} / \mathrm{F}=5.48$ ) with secondary mean age $(40.6$ years) and secondary education for the majority (47.3\%). On a professional level, the majority are specialized or multipurpose workers $(66.2 \%)$ with average seniority at the workplace (13.62 years).

Exposure to solvents:

Solvent exposure was assessed in our population according to the workstation. Two groups were identified: an exposed group (75.7\%) and an unexposed group (24.3\%). The exposure was assessed by establishing a matrix of exposure taking into account three parameters: the mode, frequency and duration of exposure and defining three exposure levels: high, moderate and low. This method was inspired by the method developed by the National Research and Safety (INRS) for the assessment of chemical hazards in the workplace. The majority of submissions (89.3\%) have an exposure level considered high or moderate.

Both groups exhibited comparable regarding age, gender and seniority to the position and disease history.

Health care consumption was assessed by the number of medical consultations over the last 12 months and by taking regularly neuropsychic medication.

Almost two thirds of the exposed have consulted at least one doctor or specialist, the number of consultations is higher than that seen in unexposed but the difference is not significant as well as consumption of drugs that are basically painkillers.

Teyssier-cottec et al. in their study looking for witnesses of early achievement of the central nervous system by solvents and conducted among a population of 75 employees divided between the exposed and unexposed to solvents, found no significant difference between these two groups with regard to medical history and use of care [8].

Moreover, both exposed and unexposed groups are comparable in terms of tobacco and alcohol. Indeed the majority of exposed and unexposed are non smokers and non drinkers.Other studies have shown a greater tendency to smoking and / or consumption of alcohol by the solvent-exposed. Hogsted $C$ showed through a meta-analysis that there is a higher consumption of alcohol by solvent-exposed [9].

Similarly, evaluation of effects of exposure to organic solvents at low doses on color vision in the paint industry has shown a homogeneous group of exposed and controls for alcohol consumption by cons Tobacco consumption seems to be higher among exposed conversely to what showed by the study directed by Teyssier and collaborator. $[6,8]$. 
Neuropsychological symptoms:

Epidemiological studies on solvents neurotoxicity date from about twenty years. They define a particular area of occupational epidemiology: neurotoxicological epidemiology. These studies have highlighted particular problems reaching cognitive function [10-13].

According to Hogstedt, the first cross-sectional study in this field was published in 1955 by Gran jeans and showed a relatively high frequency of subjective complaints of impairment of the autonomic nervous system and neurological and psychiatric symptoms among workers chronically exposed to trichlorethylene in concentration between 20 and $80 \mathrm{ppm}$. [9].

Lauwerys et al report that Scandinavian authors are the first to report that chronic exposure to vapors of various solvents can cause brain syndrome characterized by mental retardation and emotional disturbances which can lead in severe cases fortunately exceptional to dementia by brain atrophy (psycho-organic syndrome). Since then, literature has been enriched by studies (case reports, control, case control), who investigated the neurological effects associated with chronic exposure to solvents[14].

The terminology varies: "solvent induced psycho-organic syndrome (POS)", "organic solvent syndrome (PSO), chronic toxic encéphalopaty (CTE)" organic solvent encephalopaty (OSE), psycho-organic syndrome caused by solvents (SPO) "psycho-organic solvent syndrome (POS).

The existence of this syndrome is still controversial, however it is accepted by most authors. Solvents can act even in small doses on the central and peripheral nervous system, initially due to their high liposolubulity and then intervene by various mechanisms such as increases in membrane fluidity that change the flow not only intra-and extracellular nutrient but also other toxic. Some solvents may also be metabolized in the nerve cells and cause structural and biochemical changes such us cellular destruction. Others act after hepatic metabolism and the passage of metabolites beyond the blood-nerve. [14]

Finally some solvents will affect the neuro-chemical mediators. The central effect of dopamine has been demonstrated in the phenomena of addiction to tobacco and other drugs likely to solvents. ... Indeed, there are about fifteen years, researchers have realized that all drugs that cause addiction in humans have in common the release a neurotransmitter called dopamine, which affects the "reward circuit". This circuit serves as a "barometer" for human to know at any moment his mental and physical condition.

The reward circuit is composed of different brain structures in relation (prefrontal cortex, septum, amygdala and hippocampus). These four structures are linked with each other. They receive dopaminergic terminals from the ventral tegmental area and they filter the information before sending them to the area that is the ultimate regulating hypothalamus. The hypothalamus receives only information previously processed by the structures of the reward circuit knows nothing of what was happening outside. The satisfaction felt by the individual is related to dopaminergic activation, regardless of the reality of its environment. Dopamine release activates this reward circuit, generating a state of pleasure and satisfaction. It follows a change in the central nervous system that affects the overall balance and the relationship of the individual to his environment.

Dopamine release may occur several times per second. It is important that each train has a sense of liberation from the binding of the neurotransmitter on the postsynaptic receptor. To make this system work it requires that the body removes the neurotransmitter that has been issued. To do this, a process of reuptake into the neuron transmitter draws 80 to $85 \%$ of this neurotransmitter. [14] 
It is certain that the adaptability of the nervous system is so great that the first changes are insensitive to the investigations of doctors.

It remains to define clearly the psycho-organic syndrome caused by solvents and its potential stages and identify harmonized and accurate diagnostic criteria.

In 1985, classification in 3 stages and diagnostic criteria were introduced by a joint working group of WHO and the Nordic Council of Ministers. The same year a slightly different classification was proposed by a working group in Raleigh, USA

According to WHO the organic psycho syndrome is the mildest form of chronic toxic encephalopathy to organic solvents, it evolves over several days or several weeks, but does not leave scars if exposure is stopped.

According to most experts, the diagnosis of an SPO is based on:

- Professional et extra-professional anamnestic data,

- Neuropsychological and neurobehavioral testing: different batteries are used to evaluate the functions and psychomotor cognitives including battery NCTB (Neurobehavioral core test battery) proposed by WHO to monitor neurotoxic professionals effects. It has been developed since 1983, includes a coherent set of readily available tests. It is validated in many countries. It is independent of the cultural heritage, gender, age and allows comparison between studies.

- Additional tests

Currently, several authors emphasize the harmonization of diagnostic procedures using standardized methods. Similarly, a precise definition of this syndrome is necessary. Meanwhile questionnaires can help doctors in their approach and include:

- The Q16 (Swedish) (16 questions) developed by Hogstedt and al in 1984 to detect groups of subjects exposed to neuro-toxic agents and individuals at risk for further consideration.

- Q18: Q16 amended

- EuroQuest (european questionnaire) developed in 1992 by the EURONEST network to enable comparison of neuropsychiatric symptoms between epidemiological studies. It is the fruit of reflection carried out by researchers in toxicology from the European community developed initially in English and was then translated in ten languages. It includes 83 items exploring three areas: neurological and psychosomatic symptoms (impaired memory, concentration, sleep and alertness, symptoms of acute poisoning, symptoms related to personality disorders and mood) [14].

Some authors emphasized the usefulness of Q16 used as a tool for diagnosis and control of the central nervous system dysfunction [5,11]. In our study, the questionnaire was inspired from that of Q16.

In our work all employees exposed to solvents reported at least one functional neuro event and a significant difference was found with the unexposed group $(\mathrm{P}<<0.05)$. This is consistent with the results published in the literature [16 - 19]

Our study showed that the number of people with at least a neurologic complaint increases with the level of risk.

The relationship between the degree of exposure and the importance of neuropsychiatric events was suggested in several studies [17-18,21-22] which joins the results of the study CNARAT and another conducted by Langau on 349 women working in the footwear industry and exposed mainly to n-hexane and toluene [23].

Our study has identified two neuropsychiatric syndromes: 
- $\quad$ the acquired intolerance to solvent vapors

- The psycho-organic syndrome.

Acquired intolerance to solvents, which is a part of the syndrome of intolerance to chemical odor has been described by Gyntelberg in 1986. [7]

The syndrome has been selected to the following criteria:

- Having frequent headaches at the beginning of a working day or one to two hours after the onset of labor.

- Feeling of weakness of all the body with difficulty performing simple tasks. That it occurs even without physical effort or only during labor.

- Feeling faint sometimes. This sensation occurs even without physical effort and / or only during labor.

In our study, we observed two cases of intolerance syndrome to solvent vapors among expose group with a non significant difference between exposed and unexposed. Prost $G$, reported five cases of Acquired intolerance to solvents syndrome identified in various industries [24] Grimmer studied 30 cases of Acquired intolerance to solvents with a mean age of 38 years and with a slight male predominance [25]. The symptoms found in these studies are similar to those described in our patients.

A feature of the acquired intolerance to solvent syndrome is that the complaint is primarily against certain smells that are no longer supported and that trigger disorders and occur in the workplace and which disappear or improve over the weekends or work stoppages.

In our study, two patients with this syndrome has been observed had a high level of risk, but according to the literature this syndrome was observed in case of rather low exposure [25]

The diagnosis of organic solvent syndrome was selected to the following criteria:

- By returning often to see if the door is closed

- Having frequent headaches

- Having trouble sleeping

- Have the feeling of being constantly tired

- Have the feeling of weakness of all the body with difficulty performing simple tasks of decreased libido

In the literature, several studies have focused on the organic solvent psycho syndrome. [2731]. Baker identifies 13 new cross-sectional studies since 1985 involving [20] different countries and the results converge to the fact that this syndrome affects the short-term memory and psychomotor functions.

Eight employees in our study had a solvent organic psychosyndrome (14.3\% of the exposed population).

The confirmation of organic disease of the nervous system is a psychometric assessment including a battery of psychometric and clinical tests to assess the intellectual efficiency, as the battery NCTB (Neurobehavioral Core Test Battery) proposed by WHO for monitoring occupational neurotoxic effects, developed since 1983, whose contents were described by Regane in its study "interest of psychometric tests for the detection, of the neurobehavioral toxic effects of organic solvents. [21-30]

- Coherent set of easily usable tests

- $\quad$ Battery test paper and pencil

- Validated in many countries

- Independent of the cultural heritage, gender, age 
- Comparison studies

- $\quad$ Easy Implementation

- Time for total shift is about 1 hour

In the literature, the evolution of organic solvent psychosyndrome is marked by a reversible lesion if the withdrawal is sufficiently early. By cons, from stage $2 \mathrm{~B}$, the prognosis is poor $[5,27]$. Moreover, a highly significant relationship between the organic solvent psycho syndrome and exposure to solvents has been revealed in the study by Soborg in 1993 [17]

\section{Conclusion}

The solvents occupy an important place in the sector of printing for flexible packaging but also in most other industrial sectors. Our study consisted of two parts: An environmental assessment and a medical section which consisted of carrying out a transversal epidemiological study based on a predetermined questionnaire, inspired of $Q 16$ usually used for the detection of neuro-psychological effects in workers exposed to solvents.

It appears from our study that the preventative measures are absent, analysis of safety data sheets revealed the presence of several types of solvents in the composition of inks and glues. Although we note that the average concentrations measured are below the requirement for the solvents tested in all units studied. Our study population is relatively young (40.6 years) male (sex ratio $\mathrm{M} / \mathrm{F}=5.48$ ) with average tenure of 13.62 years. Neuropsychiatric complaints are frequent $(100 \%)$ and significantly higher in exposed group with a very significant difference $(<<0.05)$. The medical study identified two cases with the syndrome of acquired intolerance to solvent and eight cases of solvent organic psychosyndrome. Four cases with solvent organic psychosyndrome have received a neuropsychological exploration.

The gap between the assay results of atmospheric standards and the frequency of neuropsychiatric manifestations in exposed group incite us to reflect on the role of low doses in causing toxic effects.

Finally, in Tunisia as the medical reparation of neuropsychological damage remains difficult due to the lack of tables of occupational diseases, strengthening the technical and medical prevention is the only way that can reduce chemical risks and the socio-occupational-related neurological solvent exposure.

\section{References}

[1] A. Joffrey, F. van der Hoek, M. Maarten, Verberk and Gerard Hageman. Criteria for solvent-induced chronic toxic encephalopathy: a systematic review. Int Archiv occup Environ health 2000; 73:362-8

[2] Yu, Ignatius Tak-Sun MBBS, MPH; Lee, Nga Lan MPhil; Zhang, Xin Hua MD, PhD; Chen, Wei Qing MB, PhD; Lam, Yik Tsz MB, MMedSc; Wong, Tze Wai MBBS, MSc. Occupational Exposure to Mixtures of Organic Solvents Increases the Risk of Neurological Symptoms Among Printing Workers in Hong Kong. Journal of Occupational \& Environmental Medicine 2004; 46: 23-330

[3] Larsen, Frode, Leira, Håkon Lasse. Organic Brain Syndrome and Long-term Exposure to Toluene: A Clinical, Psychiatric Study of Vocationally Active Printing Workers. Journal of Occupational Medicine 1988; 30: 875-8 
[4] Roberta F., White PhD., Susan P., Proctor DSc., Diana Echeverria PhD., Janelle Schweikert PhD., Robert G., Feldman MD. Neurobehavioral effects of acute and chronic mixed-solvent exposure in the screen printing industry. American Journal of Industrial Medicine1995; 28: 221-31.

[5] Boillat MA. Troubles mentaux organiques d'origine toxique. Encycl Med chir, toxicologie, pathologie professionnelle $2004 ; 16-536-\mathrm{A} 70: 5 \mathrm{p} 1$

[6] Conso F, Labbe N, Yahoum A, Le syndrome psycho organique aux solvants : expérience d'une consultation de pathologie professionnelle. Arch Mal Prof 1995 ; 56 :142-44.

[7] Gyntelberg F ; verterlang, Fog P, Isâges H et Coll. Aquired intolerance to organic solvants and results of vestitular testing. Am J industr Med 1986.

[8] Teyssier-Cotte C, Mandereau L, Heman D, Moulin T, Niezborala M, Angomin M, Lamant J.M, Levyl P, Le pors. Recherche de témoins d'une atteinte précoce du sytème nerveux central par les solvants. XIIIème journée de médecine de travail, Besançon $1994 ; 138-40$.

[9] Hogstedt C, Lundberg 1, Epidémiologie des risques professionnelle neurocomportementaux : expériences méthodologiques tirées de la recherche sur les solvants organiques. Arch Mal prof $1992 ; 53: 499-506$.

[10] Abecassis J.C, Bertrand A, Thomas Alliel S, Lulinshi F. Recherche de situation de l'exposition à des doses faibles de solvants dans le BTP, Arch des maladies professionnelles $1995 ; 56: 127-28$.

[11] Dally S, Garnier R Neurotoxicité des solvants à faibles doses d'exposition. Solvants et neuropathies : données cliniques. Arch des maladies professionnelles 1995 ; 56 : 101-04.

[12] Nayrat C, Paris C, Proust B, Creau Y, Nisse C, Ragazzini L, Cailard J.F. Exposition professionnelle à de faibles doses de solvants et effets neuropsychiques : une enquête transversale.

[13] Boillat MA. Troubles mentaux organiques d'origine toxique. EMC toxicologiepathologie octobre $2004 ; 1: 178-85$. Document consulté sur internet le 16/02/2007

[14] Lawrys R, Hanfroid V, HOET P, LISON D. Toxicologie industrielle et intoxication professionnelle; 5ème édition 2007 ELSEVIER Masson.

[15] Ihring A, Triebig G, Dietz MC. Evaluation of a german version of the Q16 questionnaire for neurotoxic symptoms in workers exposed to solvents.

[16] Abecassis JC. Neurotoxicité des solvants à faibles doses d'exposition. Problèmes pratiques non rencontrés par me médecin du travail. Arch mal Prof 1995 ; 56 : 8889.

[17] Chouanière D, Fontana JM, Wild P. Troubles neuro comportementaux liés à l'exposition prolongée au toluène. Arch Mal Prof 1998 ; 59 : 330-32.

[18] Chouanière D, Nenan D. méthodes épidémiologiques pour l'étude de la neurotoxicité des solvants ; Arch Mal Prof 1995 ; 56 : 144-22.

[19] De Haro L, Jouglard J, Jahjah F, Sainty JM, Chave B, Cura B. Psycho syndrome aux solvants et recherche du syndrome d'apnée du sommeil. Arch Mal Prof 1995 ; 56 : 145-147.

[20] Baker EL. A review of recent research on health effects of human occupational exposure to organic solvent. J Occup Med $1994 ; 36$ : 1079-92.

[21] Soborg P.A, Bruhn P, Gyldensted C, Melgaard B. Chronic painters syndrome. Chronic toxic encephalopathy in house painters. Arch Neurol Scand 1979; 60 : 149-56. 
[22] Eller N, Netterstorm B, Laursen P. Risk of chronic effects on the central nervous system at low toluene exposure. Occup Med $1999 ; 1: 389-95$.

[23] Langauer-Lewowicka H, Wocka- nareck T, Braszczynoker Z et coll. Correlation of psychological and neurological changes with indicators of exposure of workers in a shoe factory to glue solvents. Med Pr $1983 ; 34: 397-04$.

[24] Prost G, Tell JP, Beget A, Davezies P, Normand JC, Intolérance acquise aux solvants, Discussion pathologisue à propos de cinq cas. Arch Mal Prof $1992 ; 53$ : 369-70.

[25] Grimmer A, Gerant C, Dupas D, Conso F. Syndrome d'intolérance aux douleurs chimiques : A propos de 30 cas. Arch Mal Prof $1995 ; 56: 149-50$.

[26] Reygane A, Fayada C, garnier R. Intérêt des tests psychométriques d'une batterie de psychologie du travail pour le dépistâge des effets toxiques neuro comportementaux des solvants organiques. Arch Mal Prof 1995 ; 56 :150-52.

[27] Dryson Ew, Ogden JA. Organic solvent induced chronic toxic encephalopathy : extent of recovery and associated factors, following cessation of exposure. Neuro Toxicology $2000 ; 21: 659-66$.

[28] Juntunen J, Anti-Poika M, Tola S, Partanen T. Clinical prognosis of patients with diagnosed chronic solvent intoxication. Acta Neurol Scand $1982 ; 65: 488-03$.

[29] Dick FD. Solvent neurotoxicity. Occup. Environ. Med. 2006 ; 63 : 221-26.

[30] Nijem K, Kristensen P, Thorud S, Al-Khalib A et Coll. Solvent exposures at shoe factories and workshops in hebron city, West Bank. Int J Occup Environ Health $2001 ; 7: 182-88$.

[31] Chenk R, Dick F, Seaton A . Health effects of solvent exposure among dochyard painters : mortality and neuropsychological symptoms. Occup Eviron. Med. 1999 ; $56: 383-87$.

[32] Normand JC, Gabet V, Davezies P, Chevallier V. Encéphalopathie toxiques chroniques aux solvants (1er cas français). Arch Mal Prof $1990 ; 51: 135-36$.

[33] Lafores LJC, Falcy M. Neurotoxicité des solvants à faibles doses d'exposition. Classification. Arch Mal Prof $1995 ; 56$ : 89-91.

[34] Moulin T, Cohe L. Neurotoxicité des solvants à faibles doses d'exposition. Diagnostic différentiel. Arch Mal Prof 1995 ; 56 : 104-09.

[35] Rouch I, Wil P, Fontana JM, Chouanière D. Evaluation of the french version of euroquest. Neurotoxicology, 2003 ; 24 :4-5 : 541-546. 


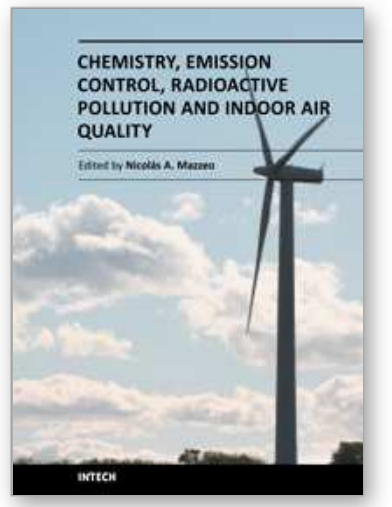

\author{
Chemistry, Emission Control, Radioactive Pollution and Indoor Air \\ Quality \\ Edited by Dr. Nicolas Mazzeo
}

ISBN 978-953-307-316-3

Hard cover, 680 pages

Publisher InTech

Published online 27, July, 2011

Published in print edition July, 2011

The atmosphere may be our most precious resource. Accordingly, the balance between its use and protection is a high priority for our civilization. While many of us would consider air pollution to be an issue that the modern world has resolved to a greater extent, it still appears to have considerable influence on the global environment. In many countries with ambitious economic growth targets the acceptable levels of air pollution have been transgressed. Serious respiratory disease related problems have been identified with both indoor and outdoor pollution throughout the world. The 25 chapters of this book deal with several air pollution issues grouped into the following sections: a) air pollution chemistry; b) air pollutant emission control; c) radioactive pollution and d) indoor air quality.

\title{
How to reference
}

In order to correctly reference this scholarly work, feel free to copy and paste the following:

Aida Benzarti Mezni and Abdelmajid Ben Jemâa (2011). Chronic Solvent Encephalopathy in a Printing Unit for Flexible Packaging, Chemistry, Emission Control, Radioactive Pollution and Indoor Air Quality, Dr. Nicolas Mazzeo (Ed.), ISBN: 978-953-307-316-3, InTech, Available from: http://www.intechopen.com/books/chemistryemission-control-radioactive-pollution-and-indoor-air-quality/chronic-solvent-encephalopathy-in-a-printing-unitfor-flexible-packaging

\section{INTECH}

open science | open minds

\author{
InTech Europe \\ University Campus STeP Ri \\ Slavka Krautzeka 83/A \\ 51000 Rijeka, Croatia \\ Phone: +385 (51) 770447 \\ Fax: +385 (51) 686166 \\ www.intechopen.com
}

\author{
InTech China \\ Unit 405, Office Block, Hotel Equatorial Shanghai \\ No.65, Yan An Road (West), Shanghai, 200040, China \\ 中国上海市延安西路65号上海国际贵都大饭店办公楼 405 单元 \\ Phone: +86-21-62489820 \\ Fax: +86-21-62489821
}


(C) 2011 The Author(s). Licensee IntechOpen. This chapter is distributed under the terms of the Creative Commons Attribution-NonCommercialShareAlike-3.0 License, which permits use, distribution and reproduction for non-commercial purposes, provided the original is properly cited and derivative works building on this content are distributed under the same license. 